南米チチカカ湖のニジマスについて

松井 佳 一

(1962 年 2 月 15 日受理)

\title{
ON THE RAINBOW TROUT (SALMO GAIRDNERII IRIDEUS) IN LAKE TITICACA SOUTH AMERICA.
}

\author{
Yoshiichi Matsur*
}

Lake Titicaca is a freshwater lake situated in Peru and Bolivia, it extents between $15^{\circ} 20^{\prime}$ and $16^{\circ} 35^{\prime}$ latitude south and between $69^{\circ}$ and $70^{\circ}$ longitude west and is 222 kilometers long and 113 kilometers across at its widest. Its total area including its 36 islands, has been calculated at about 9065 square kilometers. It is the highest navigated lake in the world, the surface of its water is 3812 meters above sea level, and fed by 25 rivers and streams which draw their waters from the snow of the mountains that fringe it. Its only outlet is the one river of Desaguadero in the south, and maximum depth is 370 meters. In my observation the surface water temperature was $14^{\circ} \sim 16^{\circ} \mathrm{C}$ in April, 1961.

During the year of 1939, Salmo trutta fario, Salmo gairdnerii irideus, Salvelinus fontinalis fontinalis and Salvelinus namaycush have been transplanted from the United States of America and Chile. They have achieved phenomenal size, especially Salmo gairdnerii irideus (rainbow trout-trucha arco iris) has grown very well and the largest one recorded is 1.22 meters in body length and 22.7 kilograms in weight.

This fact is a very interesting phenomenon on freshwater pisciculture and I affirm that Salmo gairdnerii irideus may be the landlocked form of Salmo gairdnerii gairdnerii Richard. son 1836.

私は昭和 36 年 4 月から 8 月なでボリビヤ大統領 Dr. Victor Paz Estenssoro の荘請により, 外務省 から同国へ水産資源開発の調查に派馓せられ，チチカカ竹の增殖調查は重要事項であつた。

チチカカ湖は大型船の航行 (2,000トンの气船が就航している) 寸る湖として世界最高で, 標高 $3812 \mathrm{~m}$ の高原にあつて南緯 $15^{\circ} 20^{\prime} \sim 16^{\circ} 35^{\prime}$, 西径 $69^{\circ} \sim 70^{\circ}$ にわたり, 長さ $222 \neq$, 巾 $113 \neq$ ギ, 36 の島 々を含めて面積 9,065 方キロ（瀬戸内海 9,500 方キロ，四国 18,000 万キロ）に達し，ボリビヤとペルー

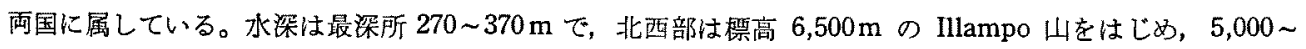
$6,000 \mathrm{~m}$ のアンデス連山につらなり水深が深く，南部は平原地带を経て車山に接し，沿岞には水深の浅い広 い地域に拡がつている。湖の周囲には 25 の河川が流入し，水源は連山の霓である。浅い沼岸には Thpha augustijolia (totra) が繁茂し，ベル一国の Puno 市付近の草謈には，このがで人工浮島を造つて，原 始的な Uros 族が住んでいる。排出口としてはペルーとボリビヤ南部国境にある Desaguaderoが唯一の河 で約 321 キロを流れて，鍼水湖で排水川がないボリビフ国の標高約 $3,700 \mathrm{~m}$ にある Lago Poopo に注い でる。

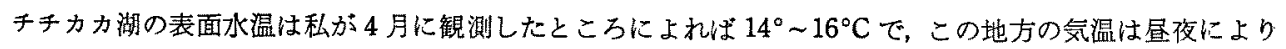
著しく翼なり, 日中 $30^{\circ} \mathrm{C}$ 近くで, 夜間の最低は $0^{\circ} \mathrm{C}$ 以下のことがある。湖の周柬には多くの都市村落があ

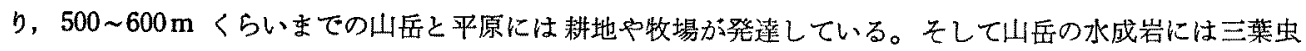
などの海原生物の化石が見出される。

\footnotetext{
* 近畿大学農学部水産学教室 (Fish. Inst., Fac. of Agr., Kinki Univ., Osaka).
} 
本湖の在来の魚類としは Pydidium pictus (mauri), Pydidium dispar (suche de lago), Pydidium rivalatum (suche), Orestias iuteus (carachi), Orestias pentlandii (boga)などの小魚が樓息している のみであつたが，1936 年からマス類の移殖が計画せられ，1939 年にはペルー国のPuno 市に近い Chucuito

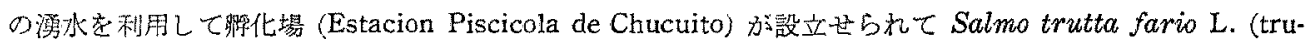
cha morena), Salmo gairdnerii irideus GrBBons, (trucha arco iris-rainbow trout), Salvelinus fontinalis fontinalis (MrTCHLL) (trucha de arroyo), Salvelinus namaycush (WALBAUM) (trucha de lago）が北米とチリーから移殖圤られた。立た，ボリビヤ国では 1943 年から放流をはじめ，湖畔 Chissi と Yungas 溪谷 Pongo に䊩化場が設立犍られた。

䔟殖せられたマス類は生長が藷しく良好で, Ilave, Escoma, Keka などの河川溯上して繁殖し，こと に二ジマ入の生長は良好で, 体長 $1.22 \mathrm{~m}$ (全長 $1.40 \mathrm{~m}$ ), 体重 $22.7 \mathrm{~kg}$ が最大型と記録せられているが,

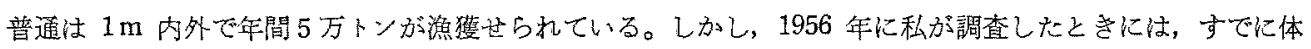
型が縮小して今度の調查ではとの傾向が著しがた。

ボリどヤ，ペルー两国では本湖のほ加各地の河川や湖にもジマスが移殖せられ，4,000 4,500 m の高 原の Lago Hichucota, Bolivia; Laguna Pomacocha; Laguna Grande, Peru などにも繁殖している。

ニジス Salmo gairdnerii irideus GIBBONS 1855 は淡水域では最大 $50 \sim 60 \mathrm{~cm}$ 内外住生育するのが

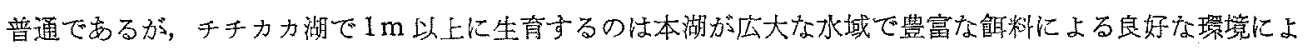

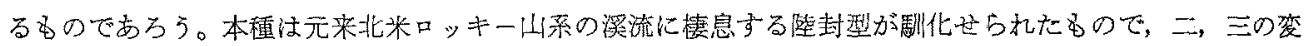
桖がある。そしてその原種としては Clemens and Wilby (1949) が Salmo gairdnerii gairdnerii RI-

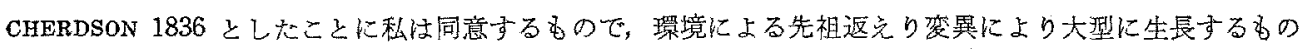

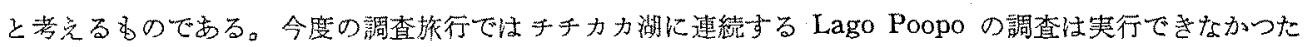

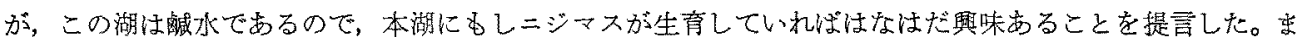
た，ニジマスが絾水湖でも大型に生育するとすれば，元来南半球の海洋には Salmonidae が分布していない

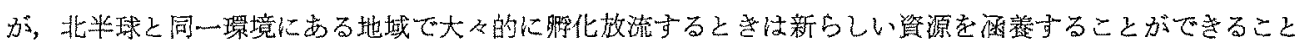
を示唆するるのでる。

\section{文献}

1) Clemens, W.A. and G.V. Wilby: 1949. Fishes of the Pacific Coast of Canada. Fisheries Research Board of Canada Bulletin No. 68.

2) GILSON, H.C.: 1939-'55. The Percy Sladen Trust Expedition to Lake Titicaca in 1937 under the leadership of Mr. H. Cary Gilson, M. A. Trans. Linnean Soc. London. 3rd. Ser. Vol. 1.

3) JAMES M. C.: 1936. A Report on Servey for Fisheries Development of Lake Titicaca. (MS).

4) OSBorn, H.: 1956. Bolivia, A Land Divided.

5) Zumudio, EnRiQue, A.: 1959. Piscicultura de la Trucha en el Peru. No. l. Ministerio de Agricultura Dereccion de Pesqueria y Caza. 